\title{
Finding of osumilite and andalusite from the Pliocene subaqueous ash layer in Niigata Prefecture, Central Japan
}

\author{
Katsuki Kurokawa*, Hiromi Konishi* and Yoshimi Fujtwara*** \\ - Department of Earth Science, Facully of Education, Niigata \\ University. Nigata 950-21, Japan \\ ${ }^{*}$ Graduate School of Science and Technology. Nitgata University. \\ Niigata $950-21$, Japan \\ *** Meike Primary School, Niigata 950-21, Japan
}

\begin{abstract}
Osumilite and andalusite phenocrysts are found from the silicic and peraluminous submarine volcanic ash layer in Nijgata Prefecture, Central Japan. The ash is intercalated in the Pliocene marine mudstone and 2-6 $\mathrm{cm}$ thick. The osumilite grains are $0.1-0.4 \mathrm{~mm}$ in size, uniaxial positive and have low $\mathrm{Mg} /(\mathrm{Mg}+\mathrm{Fe}+\mathrm{Mn})$ ratios $(0.26-0.35)$. The andalusite occurs as fresh prismatic crystals of $0.1-0.3 \mathrm{~mm}$ long. Osumilite and andalusite coexisted with melt just before the eruption, and the $\mathrm{P}-\mathrm{T}$ conditions are estimated at around $750^{\circ} \mathrm{C}$ and under less than 300 bar water pressure from the combined data for osumilite and andaiusite stability fields.
\end{abstract}

\section{Introduction}

The association of osumilite and andalusite has not been reported from the volcanic ash to date. Osumilite was first reported by Miya. shiro (1953) as a new mineral in the rhyodacite of the Osumi Province, Kyushu, Japan and thereafter it has been found from the druses and groundmass of rhyolitic and dacitic lavas, and also from the metamorphic rocks such as pyrometamorphosed rocks (Aramaki, 1961; Chinner and Dixon, 1973) and granulites (Berg and Wheeler, 1976), but its occurrence as phenocryst is not reported yet. Andalusite is common in low pressure metamorphic rocks and also found in pyrophyllite deposit (Kamitani, 1974), in the metasomatized rhyolite at Oketo, Hokkaido, Japan (Watanabe and Hasegawa, 1981), in the partly vesiculated pyrometamorphosed basement tuffs in the Sakurajima area, Kyushu, Japan (Ishihara and Kobayashi, 1988) and as xenocryst in the Kumano Acidic Rocks, Japan (Aramaki and Hada, 1965), but the occur- rence of magmatic andalusite is restricted to some granites and pegmatites (Rose, 1957; Clarke et al., 1976) and also to the glass pebbles in glacial and alluvial deposits in Peru (French and Meyer, 1970). This report aims to describe the localities and components of the osumilite andalusite-bearing ash, occurrence and chemical compositions of the osumilite and andalusite, and to consider briefly on the paragenetic implications for the $P$ - $T$ conditions of the rnagma.

\section{The osumilite andalusite-bearing ash}

The osumilite and andalusite are found from the Pliocene Suganuma-a ash (Sawaguri and Kurokawa, 1986) intercalated in the marine mudstone (the Nishiyama and Suganuma Formations) in Niigata Prefecture. Loc. 1 is at Inagawa, Izumozaki Town, $15 \mathrm{~km}$ northwest of Nagaoka City, and Loc. 2 is along the Kunis awa river, Oguni Town, $13 \mathrm{~km}$ southeast of Kashiwazaki City (Fig. 1). Loc. 1 is situated at

(Manuscript received, July 15,1990 ; accepted for publication, August 24, 1990) 


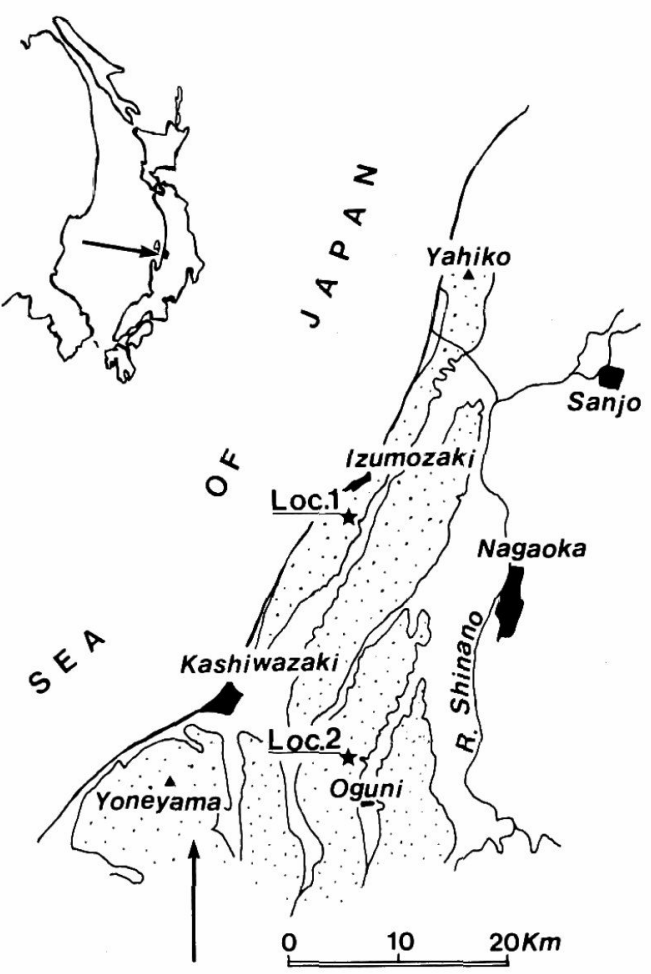

Fig. 1. Localities of osumilite and andalusite-bearing Suganuma-a ash in Niigata Prefecture : Loc. 1 is at Inagawa, Izumozaki Town and Loc. 2 is at Takeishi, Oguni Town. Blank area is alluvial.
$22 \mathrm{~km}$ north of Loc. 2.

The Suganuma-a ash is rhyolitic and vitric, and white in color. The total thickness of the ash is $2-3 \mathrm{~cm}$ at Loc. 1 and $3-6 \mathrm{~cm}$ at Loc. 2 (Fig. 2). At both localities, it is composed of more than two units. The basal unit $(2-3 \mathrm{~cm})$ is normally graded from medium sand-sized to silt-sized and the upper units are silt-sized.

Components of the ash in $68-125 \mu \mathrm{m}$ fraction are $70-80 \%$ micropumice type glass shards, 10-20\% plagioclase (andesine - labradorite) and $1 \%$ mafic minerals with a small amount of $\beta$-quartz. Some brownish glass shards and glassy volcanic fragments are also found. Accidental rock fragments are also accompanied up to $3 \%$, among which blueschist fragments are notable (alkali amphibole is $\mathrm{X}^{\prime}=$ pale blue, $Z^{\prime}=$ pale grayish violet).

Mafic mineral components are 30-50\% biotite, $20-40 \%$ hornblende $\left(\mathrm{X}^{\prime}=\right.$ dark brown, $\mathrm{Z}^{\prime}=$ dark greenish brown), $15-30 \%$ ferrosilite $(\gamma=1.740)\left(\mathrm{En}_{43} \mathrm{Fs}_{55} \mathrm{WO}_{2}\right.$ by XMA analysis), 1$3 \%$ cummingtonite $\left(\mathrm{X}^{\prime}=\right.$ pale brown, $\mathrm{Z}^{\prime}=$ pale brownish green) and 1\% almandine-spessartine garnet (pinkish orange), with a small amount of

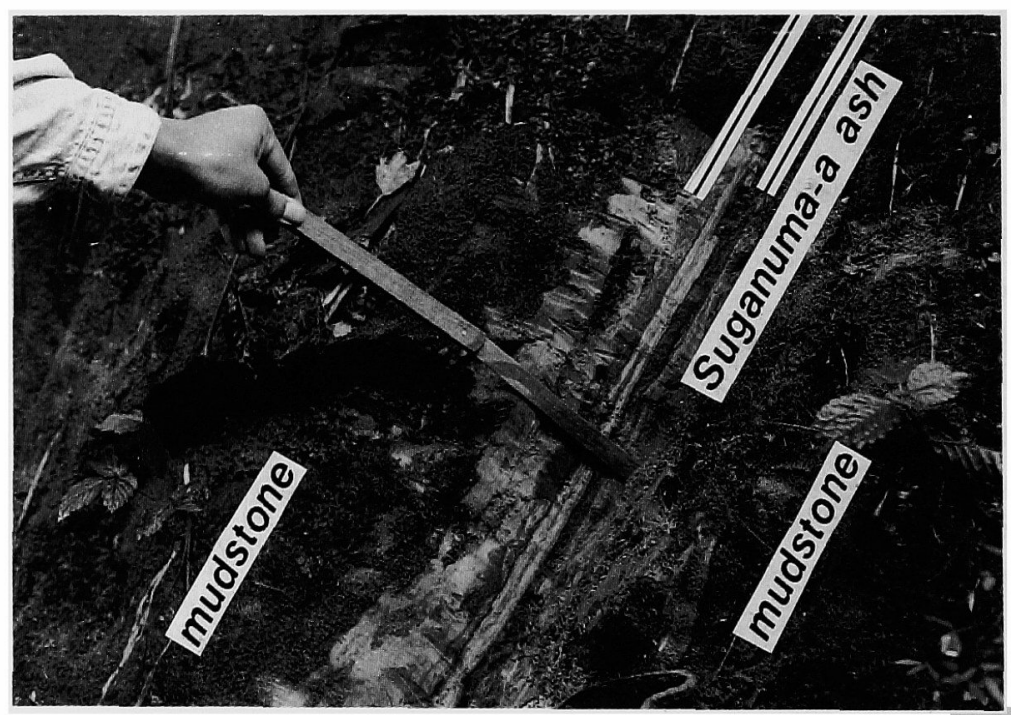

Fig. 2. Field occurrence of the Suganuma-a ash along the Kunisawa river, Takeishi, Oguni Town. The ash is intercalated in the Pliocene mudstone of the Suganuma Formation and $6 \mathrm{~cm}$ in thickness. 
augite, zircon, apatite, ilmenite, osumilite and andalusite. Osumilite content is $0.05 \%$ and andalusite is about $0.01 \%$ of the whole grains. Thus, the mineral paragenesis in the magma just before the eruption is plagioclase $+\beta-$ quart $z+$ osumilite + biotite + hornblende + cum mingtonite + ferrosilite + augite + garnet $+z$ ir con + apatite + andalusite + ilmenite with liquid (glass) and vapor.

\section{0sumilite and Andalusite}

Osumilite grains are dark blue in color and $0.1-0.4 \mathrm{~mm}$ in size. They are mostly anhedral, but fragments of the euhedral grains, partly showing straight outlines are not uncommon (Fig. 3). The osumilite grains are optically uniaxial positive, showing dichroism with $\varepsilon=$ colorless and $\omega=$ blue. Refractive indecies determined by immersion method are $\omega=1.549$, $\varepsilon=1.553$ (Loc. 1), and the lattice constants determined by electron diffraction analysis using aluminium standard are $a=10.10 \AA, c=$ $14.29 \AA$ for a single specimen from Loc. 1 . High-resolution [0001] image of the osumilite at Loc. 1 is shown in Fig. 4. Electron microscopy was performed with a JEM 200CX microscope operated at $200 \mathrm{kV}$.

$\mathrm{XMA}$ analyses of the osumilite were made at $15 \mathrm{kV}$ and $0.02 \mu \mathrm{A}$ specimen currents (Table 1). Their compositions are $\mathrm{K}>\mathrm{Na}, \mathrm{Fe}>\mathrm{Mg}$ in ionic base, and $\mathrm{Si} / \mathrm{Al}$ ratio is less than 7 , so they can be called osumilite after Bunch and Fuchs' (1969) classification. It is noteworthy that $\mathrm{Mg} /$ $(\mathrm{Mg}+\mathrm{Fe}+\mathrm{Mn})$ ranges $0.26-0.35$, which is the most $(\mathrm{Fe}+\mathrm{Mn})$-rich among optically positive
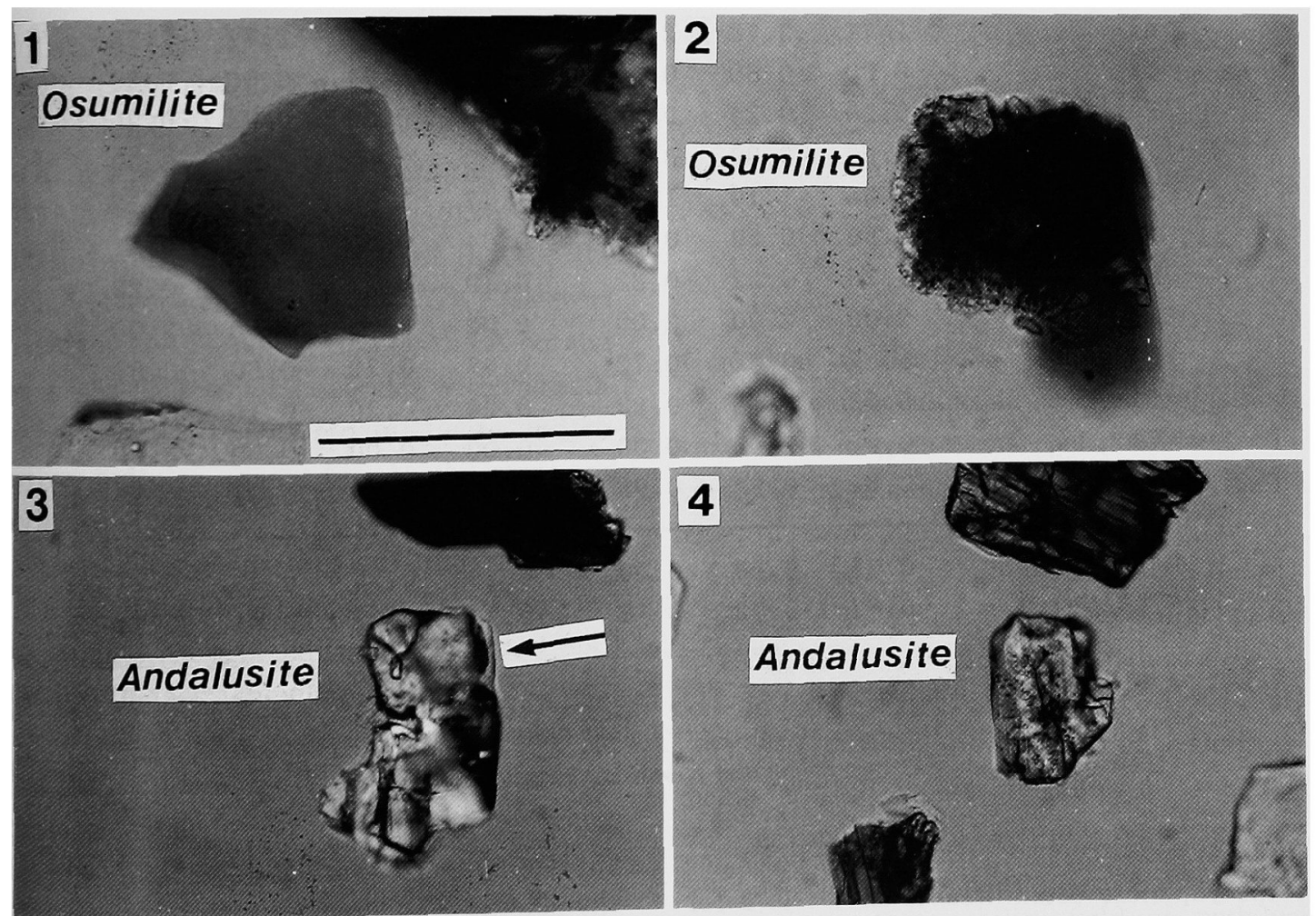

Fig. 3. Osumilite and andalusite grains in the Suganuma-a ash.

1, osumilite from Loc. 1. A scale bar indicates $0.2 \mathrm{~mm}$ (same as in 2-4) ; 2, osumilite from Loc. $2 ; 3$, andalusite from Loc. 1 . An arrow shows the glass fringe around the andalusite grain ; 4, andalusite from Loc. 2. 
Table 1. Chemical compositions of the Suganuma-a osumilites (analyzed by XMA)

\begin{tabular}{|c|c|c|c|c|c|c|c|}
\hline & \multicolumn{3}{|c|}{ Izumozaki } & \multicolumn{4}{|c|}{ Oguni } \\
\hline & 1 & 2 & 3 & 4 & 5 & 6 & 7 \\
\hline $\mathrm{SiO}_{2}$ & 60.60 & 60.46 & 60.50 & 59.96 & 59.95 & 60.98 & 60.37 \\
\hline $\mathrm{TiO}_{2}$ & 0.02 & 0.03 & 0.01 & 0.00 & 0.07 & 0.00 & 0.00 \\
\hline $\mathrm{Al}_{2} \mathrm{O}_{3}$ & 21.61 & 22.14 & 22.17 & 22.16 & 22.34 & 21.91 & 21.93 \\
\hline Feo* & 9.37 & 9.99 & 9.91 & 10.01 & 9.88 & 9.82 & 9.90 \\
\hline Mno & 1.02 & 1.52 & 1.54 & 1.34 & 1.41 & 1.33 & 1.49 \\
\hline MgO & 3.13 & 2.32 & 2.70 & 2.52 & 2.35 & 2.52 & 2.39 \\
\hline $\mathrm{CaO}$ & 0.10 & 0.00 & 0.02 & 0.01 & 0.03 & 0.00 & 0.00 \\
\hline $\mathrm{Na}_{2} \mathrm{O}$ & 0.85 & 0.79 & 0.72 & 0.80 & 0.62 & 0.46 & 0.71 \\
\hline $\mathrm{K}_{2} \mathrm{O}$ & 2.82 & 3.08 & 3.33 & 3.10 & 3.32 & 3.05 & 3.10 \\
\hline Total & 99.52 & 100.33 & 100.90 & 99.90 & 99.97 & 100.07 & 99.89 \\
\hline 0 & 30 & 30 & 30 & 30 & 30 & 30 & 30 \\
\hline Si & 10.36 & 10.31 & 10.27 & 10.27 & 10.26 & 10.38 & 10.33 \\
\hline $\mathrm{Al}$ & 1.64 & 1.69 & 1.73 & 1.73 & 1.74 & 1.62 & 1.67 \\
\hline$\Sigma$ & 12.00 & 12.00 & 12.00 & 12.00 & 12.00 & 12.00 & 12.00 \\
\hline $\mathrm{Al}$ & 2.71 & 2.76 & 2.70 & 2.74 & 2.77 & 2.77 & 2.75 \\
\hline $\mathrm{Ti}$ & 0.00 & 0.00 & 0.00 & 0.00 & 0.01 & 0.00 & 0.00 \\
\hline $\mathrm{Fe}^{3 *}$ & 0.29 & 0.24 & 0.30 & 0.26 & 0.22 & 0.23 & 0.25 \\
\hline$\Sigma$ & 3.00 & 3.00 & 3.00 & 3.00 & 3.00 & 3.00 & 3.00 \\
\hline $\mathrm{Fe}^{2+}$ & 1.05 & 1.19 & 1.10 & 1.17 & 1.19 & 1.17 & 1.17 \\
\hline $\mathrm{Mg}$ & 0.80 & 0.59 & 0.68 & 0.64 & 0.60 & 0.64 & 0.61 \\
\hline $\mathrm{Mn}$ & 0.15 & 0.22 & 0.22 & 0.19 & 0.21 & 0.19 & 0.22 \\
\hline$\Sigma$ & 2.00 & 2.00 & 2.00 & 2.00 & 2.00 & 2.00 & 2.00 \\
\hline K & 0.61 & 0.67 & 0.72 & 0.67 & 0.72 & 0.66 & 0.67 \\
\hline $\mathrm{Na}$ & 0.28 & 0.26 & 0.23 & 0.26 & 0.20 & 0.15 & 0.23 \\
\hline $\mathrm{Ca}$ & 0.02 & 0.00 & 0.00 & 0.00 & 0.00 & 0.00 & 0.00 \\
\hline$\Sigma$ & 0.91 & 0.93 & 0.95 & 0.93 & 0.92 & 0.81 & 0.90 \\
\hline $\mathrm{Mg} /(\mathrm{Mg}+\mathrm{Fe}+\mathrm{Mn})$ & 0.35 & 0.26 & 0.30 & 0.28 & 0.27 & 0.29 & 0.27 \\
\hline $\mathrm{K} /(\mathrm{K}+\mathrm{Na}+\mathrm{Ca})$ & 0.67 & 0.72 & 0.76 & 0.72 & 0.78 & 0.81 & 0.74 \\
\hline
\end{tabular}

* Total iron as FeO

1 -3, from Loc. 1 (Inagawa, Izumozaki Town); 4-7, from Loc. 2 (Takeishi, Oguni Town). $\mathrm{Fe}^{2+}$ and $\mathrm{Fe}^{3+}$ are calculated based on stoichiometry.

osumilites so far reported (Deer et al., 1982); as for the Japanese osumilites, it is $0.34-0.72$ for the Haneyama rhyolite, Oita Prefecture (Aoki, 1954; Yokomizo and Miyachi, 1978), 0.36 in the Hayato rhyolite, Kagoshima Prefecture
(Kobayashi, 1978), 0.46 in the Sakkabira rhyodacite, Kagoshima Prefecture (Miyashiro, 1956), $0.55-0.64$ in the Akagi dacite, Gunma Prefecture (Koga, 1981), 0.61 in the Iriki biotite dacite, Kagoshima Prefecture (Miyachi and 


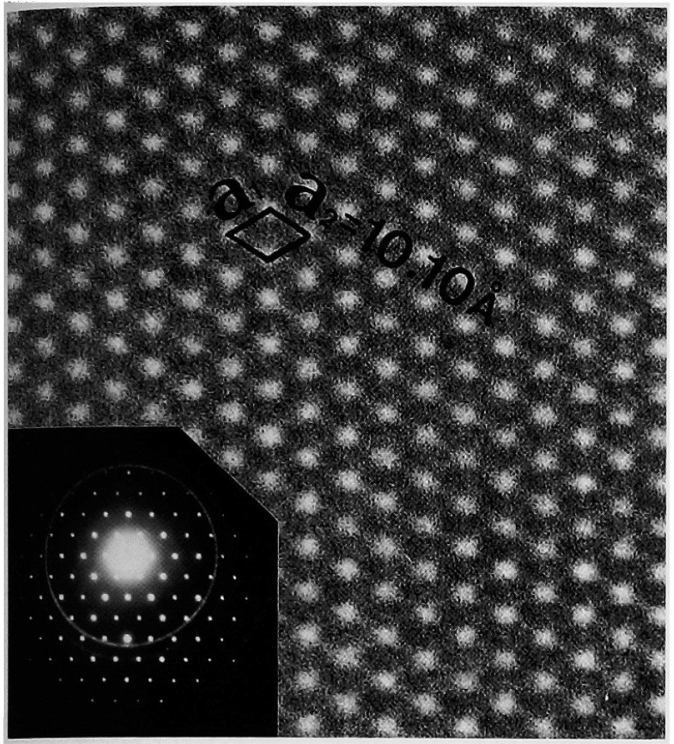

Fig. 4. High-resolution [0001] structure image of the osumilite from Loc. 1 and the corresponding [0001] zone axis diffraction pattern with Debye-Scherrer ring of $\mathrm{Al}$.

Miyachi, 1978), and 0.68 in the rhyolite of the Rishiri Island, Hokkaido (Kobayashi, 1978). $\mathrm{The} \mathrm{K} /(\mathrm{K}+\mathrm{Na}+\mathrm{Ca})$ in $\mathrm{C}$-site is in the range of $0.67-0.81$, and $\mathrm{Na}_{2} \mathrm{O}$ content (0.46-0.85\% ; $0.71 \%$ in average) is higher than that of the metamorphic osumilites $(0.22-0.59 \%$ ) (Deer et al., 1982). The Fe population on the A octahedron is $0.53-0.60$, which coincides with the relation between $\mathrm{Fe}$ population in A-site and refractive indecies given by Armbruster and Oberhansli (1988).

Andalusite grains are prismatic, mostly $0.1-0.3 \mathrm{~mm}$ in c-direction (Fig. 3). They are transparent with very pale pink tint, and optically length-fast, showing pleochroism with $\mathrm{X}=$ pale pink and $\mathrm{Y}=\mathrm{Z}=$ colorless. Alterations are not observed and mostly devoid of inclusions. Some grains have thin glass fringe (Fig. 3). This suggests that the andalusite is exclusive of xenocryst origin. Chemical composition of the andalusite by AEM analysis is listed in Table 2, using a JEM 200CX with EDS analyzer of TN2000 operated at $200 \mathrm{kV}$.
Table 2. Chemical composition (average of three grains) of the andalusite from Loc. 1 (analyzed by AEM)

\begin{tabular}{|c|c|}
\hline $\mathrm{SiO}_{2}$ & 37.0 \\
\hline $\mathrm{Al}_{2} \mathrm{O}_{3}$ & 61.9 \\
\hline $\mathrm{Cr}_{2} \mathrm{O}_{3}$ & 0.1 \\
\hline FeO* & 0.8 \\
\hline $\mathrm{MnO}$ & 0.1 \\
\hline $\mathrm{CaO}$ & 0.1 \\
\hline Total & 100.0 \\
\hline 0 & 20 \\
\hline $\mathrm{Si}$ & 4.01 \\
\hline$\Sigma$ & 4.01 \\
\hline $\mathrm{Al}$ & 7.91 \\
\hline $\mathrm{Cr}$ & 0.01 \\
\hline $\mathrm{Fe}^{3+}$ & 0.07 \\
\hline$M n$ & 0.01 \\
\hline $\mathrm{Ca}$ & 0.01 \\
\hline$\Sigma$ & 8.01 \\
\hline
\end{tabular}

*Total iron as $\mathrm{FeO}$

\section{Genetical Implications}

Phenocryst mineral assemblage indicates that the magma was peraluminous. This observation is concordant with the crystallization of osumilite and andalusite. The P-T conditions of the magma just before the eruption would have been the experimental stability fields of both osumilite and andalusite.

In the hydrous system $\mathrm{K}_{2} \mathrm{O}-\mathrm{MgO}-\mathrm{Al}_{2} \mathrm{O}_{3}$ $\mathrm{SiO}_{2}-\mathrm{H}_{2} \mathrm{O}$, the stability field of osumilite is below 800 bar water pressure. It is between $765^{\circ}$ and $800^{\circ} \mathrm{C}$ at 500 bar water pressure (Olesch and Seifert, 1981) (Fig. 5). As for $\mathrm{Al}_{2} \mathrm{SiO}_{5}$ polymorphs, the stability field of andalusite under hydrous conditions is less than $770^{\circ} \mathrm{C}$, and this temperature decreases with increasing 


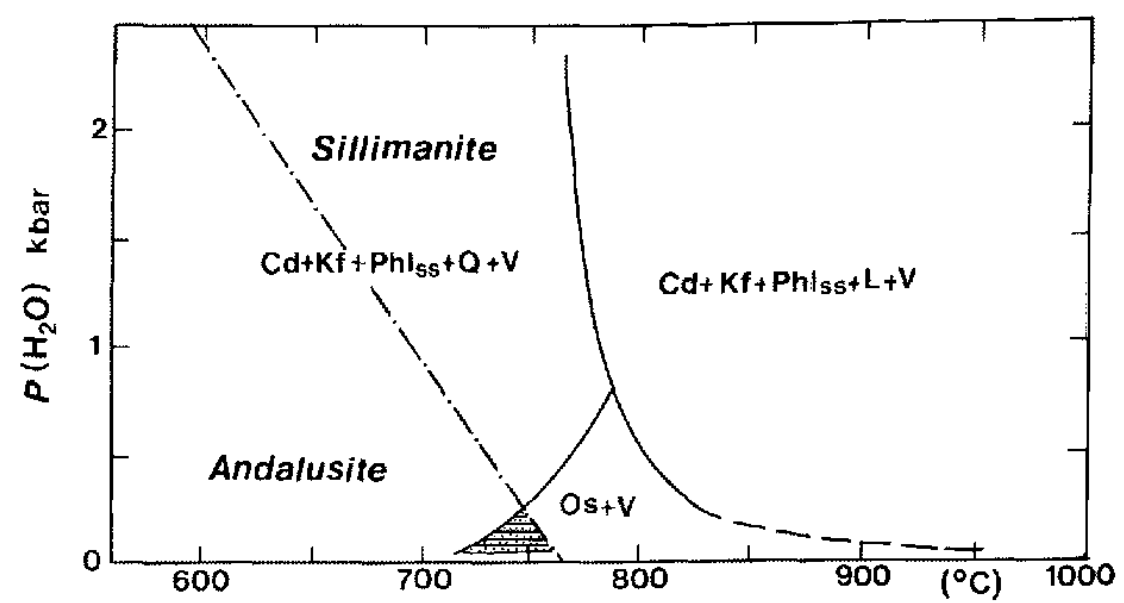

Fig. 5. Stability limits of osumilite (solid line) (Olesch and Seifert, 1981) and andalusite (dot and line) (Holdaway, 1971) at $\mathrm{P}($ total $)=\mathrm{P}\left(\mathrm{H}_{2} \mathrm{O}\right)$. The overlapped stability field of osumilite and andalusite is shown as shadowed area, (Os, Osumilite ; Cd. Cordierite; Kf, Ko feldspar; Phl $\mathrm{ss}_{\mathrm{s}}=$ Phlogopite solid solution; Q, Quartz; L. Liquid; V, Vapor).

water pressure; at $500 \mathrm{bar}$ and $730^{\circ} \mathrm{C}$ andalusite inverts to sillimanite (Holdaway, 1971) (Fig. 5). Thus, the P-T conditions of the magma just before the eruption are estimated to be around $750^{\circ} \mathrm{C}$ and less than 300 bar water pressure (Fig. 5). However, the stability field of osumilite coexisting with liquid under lower water pressures is not experimentally clarified. The eruption was probably phreatomagmatic, as deduced by the abundance of the micropumice type glass shards.

Acknowledgements: We thank to Dr. Junji Akai of Niigata University for his kind advice, Mr. Masayoshi Kobayashi of Dental Department of Nigata University for help of XMA analyses, and Messrs. Masataka Sato, Yusuke Yoshida and Masayuki Hayashi of Faculty of Education, Nitgata University for mineral separation. The authors are also grateful to unknown referees for the improvement of the manuscript. This study was partly supported by Grant-in-Aid for Scientific Research (No.62302019 and 63540607) of the Ministry of Education, Science and Culture.

\section{References}

Aoki, K. (1954), A new occurrence of osumilite. J. Japan. Assoc. Min. Petr. Econ. Geol, 38, 80 (in Japanese).

Aramaki, S. (1961), Sillimanite and cordierite from the volcanic xenoliths. Amer. Mineral., 46, 1154-1165.

Aramaki, S. and Hada, S. (1965), Geology of the central and southern parts of the acid igneous complex (Kumano Acidic Rocks) in the southeastern Kii Peninsula. J. Geol. Soc. Japan, 71, 494512 (in Japanese with English abstract).

Armbruster, T. and Oberhansli, R. (1988), Crystal chemistry of double-ring silicates: Structural, chemical, and optical variations in osumilites. Amer. Mineral., 73, 585-594.

Berg, J.H. and Wheeler. E.P. (1976), Osumilite of deep seated origin in the contact aureole of the anorthositic Nain complex, Labrador. Amer. Mineral., 61, 29-37.

Bunch, T.E. and Fuchs, L. (1969), Yagiite, a new sodium-magnesium analogue of osumilite. Amer. Mineral. 54. 14-18.

Chinner, G.A. and Dixon, P.D. (1973), Irish osumilite. Mineral. Mag., 39. 189-192.

Clarke, D.B., McKenize, C.B., Muecke, G.K. and Richardson, S.W, (1976), Magmatic andalusite from the South Mountain batholith, Nova Scotia. Contrib. Mineral. Petrol., 56, 279-287.

Deer, W.A., Howie, R.A and Zussman, J. (1982), Rock forming minerals (2nd edition), 1B, 
Disilicates and Ring silicates. 541-558, Longmans, London and New York.

French, B.M. and Meyer, H.O.A. (1970), Andalusite and ' $\beta$-quartz' in Macusani glass, Peru. Car. negie Inst. Washington. Ann. Rep. Dir. Geophys. Lab., 1968-69, 339-342.

Holdaway. M.). (1971), Stability of andalusite and the aluminum silicate phase diagram. Amer. J. Sci., 271, 91-131.

Ishihara, K. and Kobayashi, T. (1988), Recent volcamic activity at Sakurajima volcano. Bull. Vol. Soc. Japan (2nd ser), 33, 269-271 (in Japanese).

Kamitani, M. (1974), Hydrothermal alteration at the Uku "Rosekj" Mine, Yamaguchi Prefecture. Mining Geol., 24, 31 43 (in Japanese with English abstract).

Kobayashi, T. (1978), Osumilites from Rishiri Islands, Hokkaido, and Hayato cho, Kagoshima Prefecture, Rept. Fac. Sci., Kagoshima Univ. (Earth Sci. \& Biol.), no.8, 61-69 (in Japanese with English abstract).

Koga, S. (1981), On the osumilite in Chyoshichiroyama lava, Akagi Volcano, Gunma Prefecture. J. Mineral. Soc: Japan, 15, 10-17 (in Japanese).

Miyachi, S. and Miyachi, M. (1978), New occurrence of a magnesian osumilite from Iriki, Kagoshima Prefecture, Japan. Rept. Earth Sci., Dept. Gen. Educ., Kyushu Univ., 20, 1-8. Miyashiro, A. (1953), Osumilite, a new mineral, and cordierite in volcanic rocks. Proc. Japan Acad., 29, 321-323.

Miyashiro, A. (1956), Osumilite, a new silicate mineral, and its crystal structure. Amer. Mineval., 41, 104-116.

Olesch, M. and Seifert, F. (1981), The restricted stability of osumilite under hydrous conditions in the system $\mathrm{K}_{2} \mathrm{O}-\mathrm{MgO}-\mathrm{Al}_{2} \mathrm{O}_{3}-\mathrm{SiO}_{2}-\mathrm{H}_{2} \mathrm{O}$. Contrib. Mineral. Petrol, 76, 362-367.

Rose, R.L. (1957), Andalusite and corundum-bearing pegmatites in Yosemite National Park, Califomia. Amer, Mineral., 42, 635 647.

Sawaguri, M. and Kurokawa, K. (1986), Transition of volcanism from Pliocene to Pleistocene viewed from subaqueous tephra layers-an example of the Oguni region, Niigata sedimentary basin, central Japan-. Chikyu Kagakz (J. Assoc. Geol. Collab. Japan), 40, 177-191 (in Japanese with English abstract).

Watanabe, J. and Hasegawa, K. (1981), Cordieritebearing rhyolite (Oketo Rhyolite) and related rocks-.. Part 1. Some genetical considerations on formation and developing processes of the rhyolite -. Rept. Geol. Surv. Hokkaido, no. 53, 1-61 (in Japanese with English abstract).

Yokomizo, H. and Miyachi, S. (1978), Chemical composition of osumilite in Haneyama lava, Oita Prefecture. J. Japan. Assoc. Min. Petr. Econ. Geol., 73, 180m 182 (in Japanese with English abstract).

\section{新潟県の鮮新世水底堆皘火山灰から大隅石と紅柱石の発見}

\section{黑扠 勝已・小西 博巳・藤缐 啓美}

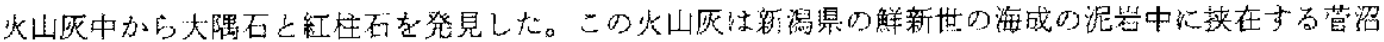

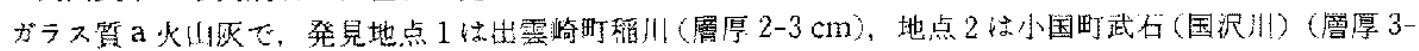

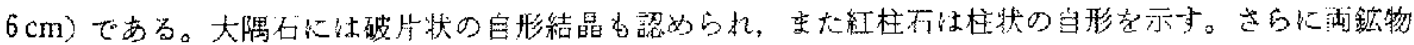

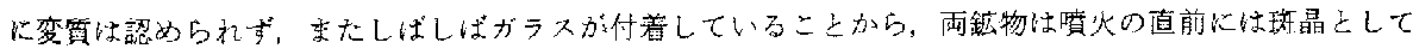

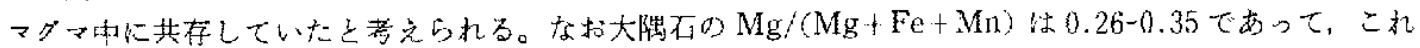

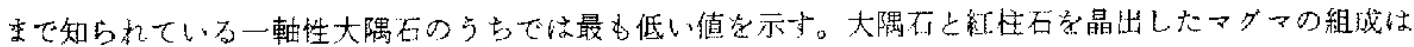
珪長質からパーアルミナスであり，ま大噴火直前の温度・压力条件は往来報告されている大隅石々紅柱石 の安它領域の重複範田が，温度 $750^{\circ} \mathrm{C}$ 程度，本蒸気圧は 300 バール以ドと推定される。 